This PDF is a selection from a published volume from the National Bureau of Economic Research

Volume Title: Social Security Programs and Retirement around the World: Fiscal Implications of Reform

Volume Author/Editor: Jonathan Gruber and David A. Wise, editors

Volume Publisher: University of Chicago Press

Volume ISBN: 0-226-31017-5; 978-0-226-31017-6

Volume URL: http://www.nber.org/books/grub07-1

Publication Date: October 2007

Title: Fiscal Effects of Social Security Reform in the United States

Author: Courtney Coile, Jonathan Gruber

URL: http://www.nber.org/chapters/c0062 


\title{
Fiscal Effects of Social Security Reform in the United States
}

\author{
Courtney Coile and Jonathan Gruber
}

The Old-Age, Survivors, and Disability Insurance (OASDI) program faces a serious long-term solvency crisis. The 2001 Trustees' Report projects that the OASDI trust funds will be exhausted in 2038 and that an immediate and permanent tax increase of 1.86 percent of taxable payroll will be needed to restore solvency for the next seventy-five years. Over the past several years, many Social Security reforms have been suggested to address the solvency crisis, from further increases in the normal retirement age to partial privatization of the system.

Many of these proposals would improve the fiscal balances of the OASDI program by cutting benefits, raising taxes, or both. However, the fiscal implications of these reforms depend critically not just on the static impacts of the reforms on benefit payments and tax collections, but also on dynamic responses of individuals to changes in program incentives. In particular, there is a large literature over the past two decades that suggests that retirement decisions are responsive to the parameters of the Social Security system. If reform alters retirement patterns, this will in turn impact benefit payments and tax collections, both inside and outside the Social Security system. For example, if raising the early entitlement age for Social Security leads to later retirement, this may significantly improve the government's fiscal position, above and beyond the savings from starting payments later in life.

Courtney Coile is an associate professor of economics at Wellesley College and a faculty research fellow of the National Bureau of Economic Research (NBER). Jonathan Gruber is a professor of economics at the Massachusetts Institute of Technology and a research associate of the National Bureau of Economic Research.

The authors thank David Wise and other members of the International Social Security Working Group for helpful suggestions. 
While some previous studies of Social Security and retirement have forecast the effect of various reforms on labor supply, little work in the United States has focused on the impact of reforms on the fiscal position of the federal government. There has been little attempt, to date, to marry dynamic models of retirement responsiveness to estimates of the impact of reform on fiscal balances.

We propose to incorporate labor supply responses into our simulations of the effect of Social Security reforms on older workers' net fiscal contributions to OASDI. Such reforms will have both an automatic effect on fiscal balances by changing contributions and benefits for a given work history (the mechanical effect), and an additional effect through labor supply responses to the reform (the behavioral effect). We estimate the fiscal implications of both the mechanical and the behavioral effect, using retirement models to predict labor supply responses. The result will be an estimate of the steady-state impact of the reforms on the financial balance sheet of the OASDI program. We also include income and consumption taxes in our analysis in order to examine the effect of the reforms on total government finances.

To be clear, we are not engaging in a full-blown solvency analysis along the lines of that carried out by the Social Security Administration (SSA). We do not consider the impact of reform on both transition and long-run system finances. Rather, for illustrative purposes, we follow one cohort of workers and illustrate the impacts of reforms on the benefits paid to, and the taxes collected from, this cohort. This gives some guide as to the percentage effects of reforms on system balances.

The remainder of the chapter is organized as follows. In section 12.1, we provide some background on the Social Security program and on previous literature on social security and retirement. In section 12.2 , we discuss the data and empirical strategy we employ to estimate the effect of reforms on workers' net fiscal contributions to OASDI. In section 12.3, we present our results. In section 12.4, we analyze the distribution effects of the proposed policy changes. In section 12.5 , we conclude.

\subsection{Background}

\subsubsection{Institutional Features of Social Security}

As this paper focuses on labor supply responses to Social Security reform, a brief overview of the Social Security program is necessary to understand how the program affects retirement; see Diamond and Gruber (1998) for a more detailed review. An individual is entitled to retired worker benefits once he or she has worked forty quarters in covered employment. Benefits are calculated in several steps. Annual earnings are indexed by an average wage index, and the thirty-five highest years of earnings are used 
to compute the average indexed monthly earnings (AIME). ${ }^{1} \mathrm{~A}$ progressive formula is applied to the AIME to obtain the primary insurance amount (PIA). Finally, the PIA is adjusted to obtain the monthly benefit amount based on when benefits are first received. Individuals claiming at the normal retirement age (NRA, legislated to grow slowly from 65 to 67) receive the PIA. Individuals can receive benefits as early as age 62 (the early retirement age, or ERA), or can delay until age 70 . Benefits are reduced by 6.67 percent for each year of receipt prior to the NRA and are increased by a delayed retirement credit of 3 percent to 8 percent for each year receipt is postponed past the NRA, depending on the worker's birth year. ${ }^{2}$ Benefit receipt is subject to an earnings test before age 65 , whereby earnings above a floor amount reduce current benefits and cause them instead to be paid out (with an actuarial adjustment) upon full retirement. Spouses of beneficiaries also receive a dependent benefit equal to 50 percent of the worker's PIA or a survivor benefit equal to 100 percent of the worker's PIA, although the spouse receives only the larger of this and his or her own retired worker benefit. Benefits are funded with a payroll tax of 12.4 percent, paid half by employers and half by employees.

Additional work affects social security wealth in several ways. First, the additional year of earnings may replace an earlier year of zero or low earnings in the AIME calculation, raising the monthly benefit. Second, work beyond age 62 implies a delay in claiming benefits (if earnings are significantly above the earnings test floor). Benefits are forgone for a year, but future benefits are higher due to the actuarial adjustment. Finally, additional work results in additional payroll taxes. The combination of these three effects determines whether the Social Security system provides a return to additional work that is more or less than actuarially fair.

\subsubsection{Previous Related Literature}

While there is little work that has incorporated labor supply responses to Social Security reforms into estimates of the effect of reforms on the government's fiscal position, there is a large previous literature that has explored the effect of Social Security on retirement decisions. A brief overview of this literature follows; for a more detailed review, see Diamond and Gruber (1998).

While a few studies have used aggregate information on the labor force behavior of workers at different ages to infer the role played by Social Security, most studies have attempted to specifically model the role that benefits play in determining retirement decisions. ${ }^{3}$ Early studies estimated

1. Earnings after age 60 are in nominal dollars, increasing the incentive to work at these ages.

2. The delayed retirement credit (DRC) is rising from 3 percent for workers born prior to 1925 to 8 percent for workers born after 1942. For workers with an NRA above 65 , benefits are reduced 5 percent per year for receipt more than three years before the NRA.

3. Hurd (1990) and Ruhm (1995) are good examples of studies using aggregate data. 
reduced-form models of the retirement decision as a function of social security wealth, ${ }^{4}$ however, more recent literature has also incorporated increases in wealth resulting from additional work. Some studies did this by incorporating the accrual of social security wealth resulting from one additional year of work, others by estimating structural models of retirement decisions by workers facing a lifetime budget constraint. ${ }^{5}$ Typically, these studies found that Social Security played an important role, albeit one that could only explain a fraction of the decrease in older men's labor supply during the post-WWII era.

Stock and Wise $(1990 \mathrm{a}, \mathrm{b})$ made the important observation that it is not simply the increment to retirement wealth with one additional year of work that matters, but rather the entire evolution of future wealth with further work. They developed an option value model that posited retirement decisions as a function of the difference between the utility of retirement at the current date and at the date that maximizes one's utility. The critical contribution of this approach is to model retirement decisions in a forward-looking framework that considers the impact of the path of future incentives on retirement. This approach was extended from firmspecific to national data by Samwick (1998), and it shows once again the modest effects of Social Security, but much larger effects of private pensions.

Coile and Gruber (2000) recognized that the vast majority of variation across individuals in option value resulted from wages, and they developed an alternative measure - peak value - that measures the financial gain from delaying retirement to the age at which social security wealth is maximized. They also found that Social Security has a significant but modest effect on retirement decisions.

A final relevant article is Coile and Gruber (2001), which explores whether the Social Security program provides strong incentives or disincentives for work at particular ages. They find that, once payroll taxes are included, the median male worker faces a small tax on work through the Social Security system at ages 55 to 61 , a near-zero tax at ages 62 to 64 , and a large tax at ages 65 to 69 . The actuarial unfairness of the system at some ages suggests that labor supply responses to Social Security reforms may have a beneficial effect on the government's fiscal position if the reforms encourage more years of work at those ages.

4. For more recent examples of this literature, see Diamond and Hausman (1984) and Blau (1994).

5. For examples of the former, see Fields and Mitchell (1984) and Hausman and Wise (1985); for examples of the latter, see Burtless (1986), Gustman and Steinmeier (1985, 1986), and Rust and Phelan (1997). 


\subsection{Data and Empirical Strategy}

\subsubsection{Data}

The data used in the analysis is the Health and Retirement Study (HRS). This is a survey of persons born 1931-1941 and their spouses, with interviews every two years, starting in 1992. The HRS contains extensive information on employment, health, and family structure. For the purposes of this paper, the critical feature is that the HRS is linked to Social Security earnings histories, allowing accurate calculation of the retirement incentives arising from Social Security. ${ }^{6}$

The sample for the analysis is all men and single women in the 1931-1941 birth cohorts who are working at age 55 and have nonmissing Social Security records for themselves and their spouses. Benefits accruing to married women are included in their husband's record (this includes the women's retired worker, dependent, and survivor benefits). We assume that married women retire at the initial ERA, that is, at 62 . When we simulate reforms to the system, we continue to assume that women retire at 62 and claim benefits at the first availability. The purpose of maintaining the same retirement age is to avoid building a behavioral response of women into the mechanical effect. The final sample size is 3,060 persons.

For each person in our sample, we have earnings histories that can allow us to compute his or her Social Security benefit entitlement at each retirement age (or age of death). The critical assumption involved in doing so is projecting his or her earnings into future years. In our earlier work, we found that these projections work best if we assume no real earnings growth from the current age forward until retirement. Given these earnings projections, we can also compute the payroll tax obligations of workers at future ages.

A key contribution of our simulations is that we will consider the impact on the entire government fiscal position, not just on Social Security in a vacuum. Doing so requires modeling the impact of additional years of work on income and consumption tax revenue as well, and we subsequently describe our approach for doing so. This approach does not provide a perfect picture of the full fiscal impact of reforms. For example, there will be effects on other, much smaller retirement income support programs when Social Security is reformed, such as the Supplemental Security Income (SSI) program. But these effects are difficult to model, since these other programs may also change through reform. We assume that the

6. The HRS also includes information from employers on private pensions. In this analysis, we will ignore pensions, as our focus is on Social Security reform, and it is difficult to forecast how pensions might change in response to a change in Social Security rules. 
effects are sufficiently modest that they do not bias our overall assessment of the fiscal implications of reform.

\subsubsection{Empirical Strategy}

Our goal is to estimate how changes to the Social Security program would affect the net fiscal position of OASDI with respect to a particular cohort of workers, those born between 1931 and 1941, who were working at age 55. Once again, this approach is not designed to provide a full picture of the full implications of reform for program solvency. Rather, it provides a snapshot of the relative magnitude of effects that may be observed when reform impacts a particular slice of birth cohorts.

We calculate social security wealth in the base case for our sample of age-55 workers and their families using the following approach. Each age55 worker will exit the labor force sometime over the next twenty years, either by retiring or by dying prior to retirement. ${ }^{7}$ Thus, there are forty possible exit paths out of the labor force, or forty states of the world, corresponding to retirement or death at each age from 55 to 74 . We obtain the weighted average social security wealth by multiplying the probability of each state by the social security wealth received in that state.

The probability of each state is obtained as follows. We calculate the conditional probability of dying at each age from age- and sex-specific U.S. life tables. ${ }^{8}$ We calculate the probability of retiring at each age conditional on being in the labor force using models of retirement behavior from Coile and Gruber (2004). ${ }^{9}$ The central results from that paper are reproduced in table 12.1. We estimate retirement models as a function of both the level of social security wealth (the expected PDV of net transfers from the Social Security system from your current age forward), and two different dynamic measures of retirement incentives. The first is option value, as pioneered by Stock and Wise (1990a, b). This measure, as previously noted, captures the difference between the utility of retiring today and retiring at the age when utility is maximized, as a function of both future wages and retirement benefit entitlements. Thus, if this is positive, then there are gains to delaying retirement, and these gains rise with the value of the option value term (so that we expect a negative impact of option value on retirement). The second is the peak value, as described in Coile and Gruber (2000). This measure focuses solely on retirement income as opposed to total financial returns to work, in order to distinguish retirement-income effects from wage

7. For the purpose of our calculation, we will assume everyone retires by age 74 . We do not use workers' observed labor force exit, as many workers will not have exited the labor force by the 2000 HRS. Rather, we use projected labor force exits from the empirical models described herein.

8. Life tables are from the 1995 OASDI Trustees Report, intermediate assumptions case.

9. To be precise, this probability is also conditional on being alive at the beginning of this age and not dying at this age. Thus, 100 percent of workers at each age are accounted for either through exit to death, exit to retirement, or continued labor force participation. 


\begin{tabular}{|c|c|c|c|c|}
\hline & \multicolumn{4}{|c|}{ Incentive variable } \\
\hline & \multicolumn{2}{|c|}{ Peak value } & \multicolumn{2}{|c|}{ Option value } \\
\hline & $\begin{array}{c}\text { Age } \\
\text { dummies }\end{array}$ & $\begin{array}{l}\text { Linear } \\
\text { age }\end{array}$ & $\begin{array}{c}\text { Age } \\
\text { dummies }\end{array}$ & $\begin{array}{l}\text { Linear } \\
\text { age }\end{array}$ \\
\hline \multicolumn{5}{|c|}{ Male sample } \\
\hline SSW & $\begin{array}{c}0.1996 \\
(0.1395)\end{array}$ & $\begin{array}{c}0.2926 \\
(0.1344)\end{array}$ & $\begin{array}{c}0.1249 \\
(0.1363)\end{array}$ & $\begin{array}{c}0.2010 \\
(0.1331)\end{array}$ \\
\hline$\$ 10,000$ change & $(0.0016)$ & $(0.0025)$ & $(0.0010)$ & $(0.0017)$ \\
\hline Incentive measure & $\begin{array}{c}-0.6618 \\
(0.2750)\end{array}$ & $\begin{array}{c}-0.4983 \\
(0.2927)\end{array}$ & $\begin{array}{c}-0.2106 \\
(0.0522)\end{array}$ & $\begin{array}{c}-0.2368 \\
(0.0539)\end{array}$ \\
\hline$\$ 1,000$ change & $(-0.0005)$ & $(-0.0004)$ & & \\
\hline Pseudo $R^{2}$ & 0.1386 & 0.1386 & 0.1402 & 0.1402 \\
\hline \multicolumn{5}{|c|}{ Female sample } \\
\hline SSW & $\begin{array}{c}0.2574 \\
(0.1315)\end{array}$ & $\begin{array}{c}0.2881 \\
(0.1320)\end{array}$ & $\begin{array}{c}0.2200 \\
(0.1323)\end{array}$ & $\begin{array}{c}0.2485 \\
(0.1331)\end{array}$ \\
\hline$\$ 10,000$ change & $(0.0020)$ & $(0.0022)$ & $(0.0017)$ & $(0.0019)$ \\
\hline Incentive measure & $\begin{array}{c}-0.0307 \\
(0.3350)\end{array}$ & $\begin{array}{c}-0.0878 \\
(0.3345)\end{array}$ & $\begin{array}{c}-0.2441 \\
(0.0753)\end{array}$ & $\begin{array}{c}-0.2723 \\
(0.0773)\end{array}$ \\
\hline$\$ 1,000$ change & $(-0.00002)$ & $(-0.00007)$ & & \\
\hline Pseudo $R^{2}$ & 0.1530 & 0.1530 & 0.1530 & 0.1549 \\
\hline
\end{tabular}

Notes: Dependent variable is whether the individual retires this year. Peak value and social security wealth (SSW) are in 100,000s of \$1992; option value is in 10,000. Regressions include controls for education, race, experience, marital status, industry, occupation, region, and year, as well as a quartic in earnings, a quartic in lifetime earnings, and the interactions of these quartics (plus same earnings variables for the spouse).

effects (which might be unobservably correlated with tastes for work). So this measure is the difference between the maximum value of the PDV of retirement income and the value if the individual retires today. Once again, as peak value is larger, the returns to delaying retirement rise, so that we expect a negative coefficient in a retirement equation.

Both models also include controls for age, flexible functions of earnings and lifetime earnings, and education, race, region, industry, and occupation dummies. A central issue, which is the focus of our earlier paper, is the correct approach to specifying the impact of age in these retirement models, particularly the use of age dummies versus linear age. If there are strong correlations between wealth or dynamic incentives and particular ages, then including age dummies might absorb some of the impacts of the program on retirement decisions. On the other hand, if there are nonlinear impacts of age on retirement decisions, then including a linear age term may lead to biased estimates of the program's incentive effects. Thus, we estimate the models both ways in table 12.1.

In this work, we have found fairly consistent evidence for significant 
effects of program incentives on retirement decisions. Table 12.1 shows the key coefficients from these models. In each cell, we show the probit coefficient, the associated standard error, and the impact of a $\$ 10,000$ increment to SSW, or a $\$ 1,000$ increment to peak value. For men, peak value and option value each have a negative and significant effect on retirement, while social security wealth has a positive, though not always significant, effect. The results suggest that each $\$ 10,000$ in social security wealth raises the odds of retirement by 0.1 to 0.25 percentage points, from a rate of 5.7 percentage points. Each $\$ 1,000$ in peak value, on the other hand, lowers the odds of retirement by 0.04 to 0.05 percentage points. We can't really interpret the option value coefficient as such, since it is in utility terms. Our results are fairly similar for women. The major differences are that the SSW terms are more consistently significant, and the peak value terms are now insignificant.

We apply the coefficients from those models to each individual's characteristics to obtain a predicted probability of retirement at each age for each individual. That is, this model provides us with baseline estimates of retirement by age.

Next, the expected net present discounted value of social security wealth is calculated for each possible labor force exit path (retirement or death at each of the twenty ages 55 to 74). For single workers, social security wealth is simply a sum of future benefits, discounted by time preference and survival probabilities. For married workers it is more complicated, since we must include dependent spouse and survivor benefits and retired worker benefits for the spouse, and account for the joint likelihood of survival of the worker and dependent. We use a real discount rate of 3 percent and survival probabilities from the age- and sex-specific life tables. Finally, we multiply the probability of each state times the social security wealth in that state for each individual, then average over all individuals to obtain the average base case social security wealth for the sample.

This same approach can then be used to compute the fiscal implications of reform, in two steps. First, we measure the impact of reform on both social security wealth and on option/peak value at each age. We can then use these new post-reform values to compute a new odds of retirement at each age, based on our regression coefficients in table 12.1. We assume that mortality is not affected by reform. Second, we multiply these new odds of exit by the new stream of net SSW from either death or retirement at each age. In this way, we obtain the new fiscal position for this cohort from reform.

As this discussion makes clear, however, there are two distinct effects of reform that are of interest: the fiscal effects of reform that arise automatically due to changes in program rules, and those that arise due to labor supply responses. The mechanical effect is the change in social security wealth that arises solely from the change in program rules, holding retirement probabilities constant, while the behavioral effect is the additional 
change in social security wealth that results from the change in retirement probabilities, holding wealth constant at its postreform level. The fiscal implications of the mechanical and behavioral effects are calculated as follows:

$$
\begin{aligned}
\text { Mechanical effect } & =\sum_{i=1}^{N} \sum_{s=1}^{48} P_{i s}^{B} S S W_{i s}^{R}-\sum_{i=1}^{N} \sum_{s=1}^{48} P_{i s}^{B} S S W_{i s}^{B}, \\
\text { Behavioral effect } & =\sum_{i=1}^{N} \sum_{s=1}^{48} P_{i s}^{R} S S W_{i s}^{R}-\sum_{i=1}^{N} \sum_{s=1}^{48} P_{i s}^{B} S S W_{i s}^{R}, \\
\text { Total effect of return } & =\sum_{i=1}^{N} \sum_{s=1}^{48} P_{i s}^{R} S S W_{i s}^{R}-\sum_{i=1}^{N} \sum_{s=1}^{48} P_{i s}^{B} S S W_{i s}^{B},
\end{aligned}
$$

where $i$ is individual, $s$ is state (exit to death or retirement at each age), $B$ is base, and $R$ is reform. Thus, the mechanical effect is the impact of letting SSW change from before to after reform, but holding retirement behavior constant; the behavioral effect is the impact of letting exit probabilities change from before to after reform, but holding SSW constant. The sum of the mechanical and behavioral effects is equal to the total effect.

The net present discounted value of income and consumption taxes are computed using the same methodology as social security wealth. Again, there are forty possible exit paths out of the labor force, and each path corresponds to certain expected future income flows. For example, in the case where the worker retires at age 55, there are three possible amounts of household income in each future year, depending on whether the husband, wife, or both are alive in that year. Taxes are computed for each of the three possible income amounts, then the stream of taxes is discounted for time preference and mortality risk. The income taxes paid each year are calculated using a simple tax calculator based on the 2000 U.S. income tax code; households are assumed to take the standard deduction and tax rules regarding the taxation of Social Security benefits are incorporated. Consumption taxes are assumed to be 4.5 percent of income; 4.5 percent is the ratio of state and local sales and excise taxes to personal disposable income for 2000 .

\subsection{Results}

\subsubsection{The Reforms}

We simulate three different reforms to the U.S. Social Security system. The first reform is a three-year increase in the ERA and NRA, to 65 and 68, respectively (Three-Year Reform). This reform will significantly reduce social security wealth at any age, since benefits receipt begins much later in life. The reform will also reduce incentives for continued work at younger ages, since the peak value of SSW is so much lower; but it will increase 
incentives for work after age 65 , since the actuarial adjustment is now so much larger in that age range.

The second reform is a change in the actuarial adjustment, to 6 percent per year (Actuarial Reform). This is actually only a small change to the current U.S. system, since the actuarial adjustment is equal to 6.67 percent between ages 62 and 65 and is between 5 percent and 7.5 percent above age 65 for workers in these birth cohorts. But this is a much larger change in the other countries in this project, which do not currently have actuarial adjustments. In the U.S. context, this change will lead to a reduction in SSW at younger ages, which will promote retirement, but also a reduction in the dynamic incentive to continue work. At older ages, the effects will vary by birth cohort.

The third reform is a move to a system with a flat 60 percent replacement rate of the AIME at age 65, an early eligibility age of 60 , and a 6 percent annual actuarial adjustment between ages 60 and 70 (Common Reform) ${ }^{10}$ The third policy is not viewed as being a realistic policy reform for the United States, but is presented to illustrate the effects of moving to a more generous system, more similar to those in European countries. This policy will significantly increase social security wealth, leading to earlier retirement, but will also significantly increase the financial benefits to longer work life, since the dollar benefits from additional work are rising so substantially, while the actuarial adjustment is similar to current law.

One issue that arises in simulating policy reforms is how the reforms will affect individuals' tendency to retire at particular ages, as reflected by the age dummies in the retirement model. For example, two of the three policies change the early retirement age, and it seems quite likely that the spike in the retirement hazard at age 62 might be altered as a result of the change. However, it is difficult to predict exactly how the retirement hazard might change. We propose to deal with this issue by using two alternative assumptions about the age dummies. The first is to leave the age dummies unchanged by the policies, and the second is to shift the age dummies as seems appropriate. For the first policy, we shift the age dummies back by three years, so that the age 62 spike is moved to age 65 , the age 65 spike to age 68 , and so on. For the second policy, the age dummies are unaffected, while for the third policy, we shift the age 62 dummy to age 60 and make several other small adjustments. We also present results using the linear age model.

\subsubsection{Results}

The results of the analysis for the typical age- 55 household, averaging over married couples and singles, are shown in table 12.2. We present six panels, corresponding to the six specifications we estimate: linear age,

10. This system also has a 100 percent survivor benefit, though no dependent spouse benefit. 


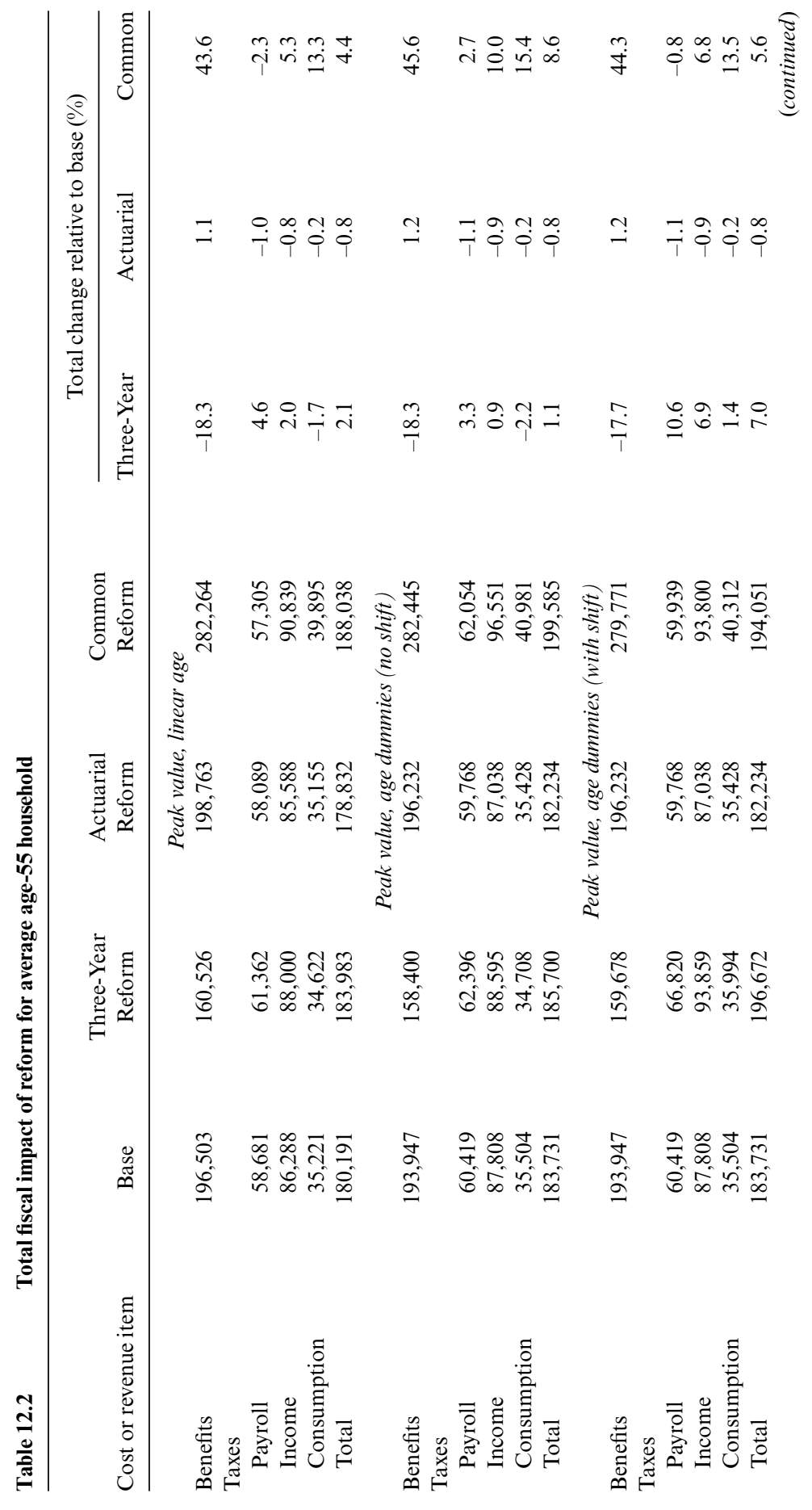




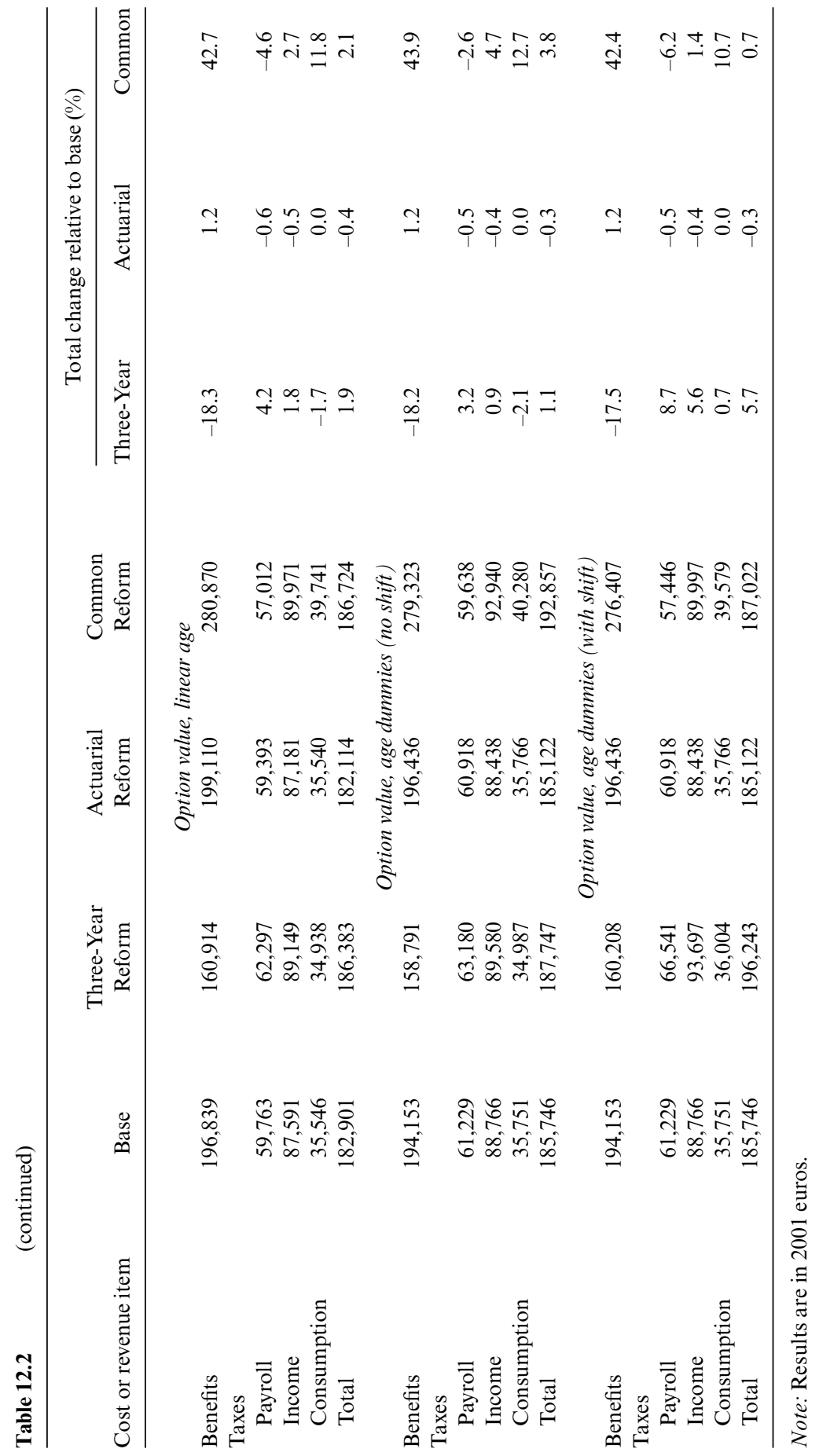


age dummies with no shift in their value from reform, and age dummies with a shift in value from reform, each for the peak and option value models. In each panel, we show rows for: Social Security benefits, payroll taxes, income taxes, consumption taxes, and total tax payments. We show columns for the base case, and then for each of the three reforms. Finally, the last three columns show the percentage effects from each of the three reforms.

Consider the first panel, which shows the peak value model, with linear age controls. In the base case, averaging over the forty possible labor force exit paths, the typical age-55 household has expected future Social Security benefits of $€ 196,503$ (2001 euros), expected future Social Security payroll taxes of $€ 58,681$, and expected total future taxes of $€ 180,191$. It is important to note that the majority of future tax payments come not from payroll taxes but from income taxes. This highlights the value of government-wide simulations, as opposed to simulations that focus on the Social Security system in a vacuum.

The total effect of the Three-Year Reform is to lower benefits, in this case by 18.3 percent to $€ 160,526$. Payroll taxes rise, as do income taxes, due to longer working lives. But consumption taxes fall, as the higher labor income does not offset lower Social Security benefits, leading to falling disposable income. In total, tax revenues rise by 2.1 percent, to $€ 183,983$.

The effect of the Actuarial Reform is much smaller; benefits rise by only 1.1 percent and taxes fall by 0.8 percent. The effect of the Common Reform is the largest of all, with a rise in benefit payments of 43.6 percent and a total rise in tax payments of 4.4 percent. All six models (peak value versus option value, linear age versus age dummies, with or without shift) generate similar predictions of the effect of the reforms on benefits, though the effect of the reforms on taxes varies more across the models.

Table 12.3 decomposes the total effect of reform into two components, the mechanical effect and the behavioral effect. Once again, we present one panel for each estimated model. Each panel has three sets of columns for the three reforms. In each set of columns, we show the mechanical effect, the behavioral effect, and the total effect of reform.

In the case of Social Security benefits, the mechanical effect is responsible for the vast majority of the total effect. For example, in the peak value model with linear age controls, the Three-Year Reform mechanically cuts benefits by $€ 35,934$. Incorporating labor supply responses to the reform has an additional beneficial effect on program solvency, but the effect is very small: benefits drop by a further $€ 44$, or less than 0.1 percent of base case benefits. In some of the other models, the behavioral response to this reform actually results in an increase in benefits - for example, in the option value model with age dummy shift, benefits rise by $€ 1,249$. However, in all models, the magnitude of the behavioral effect remains very small relative to the magnitude of the mechanical effect. 


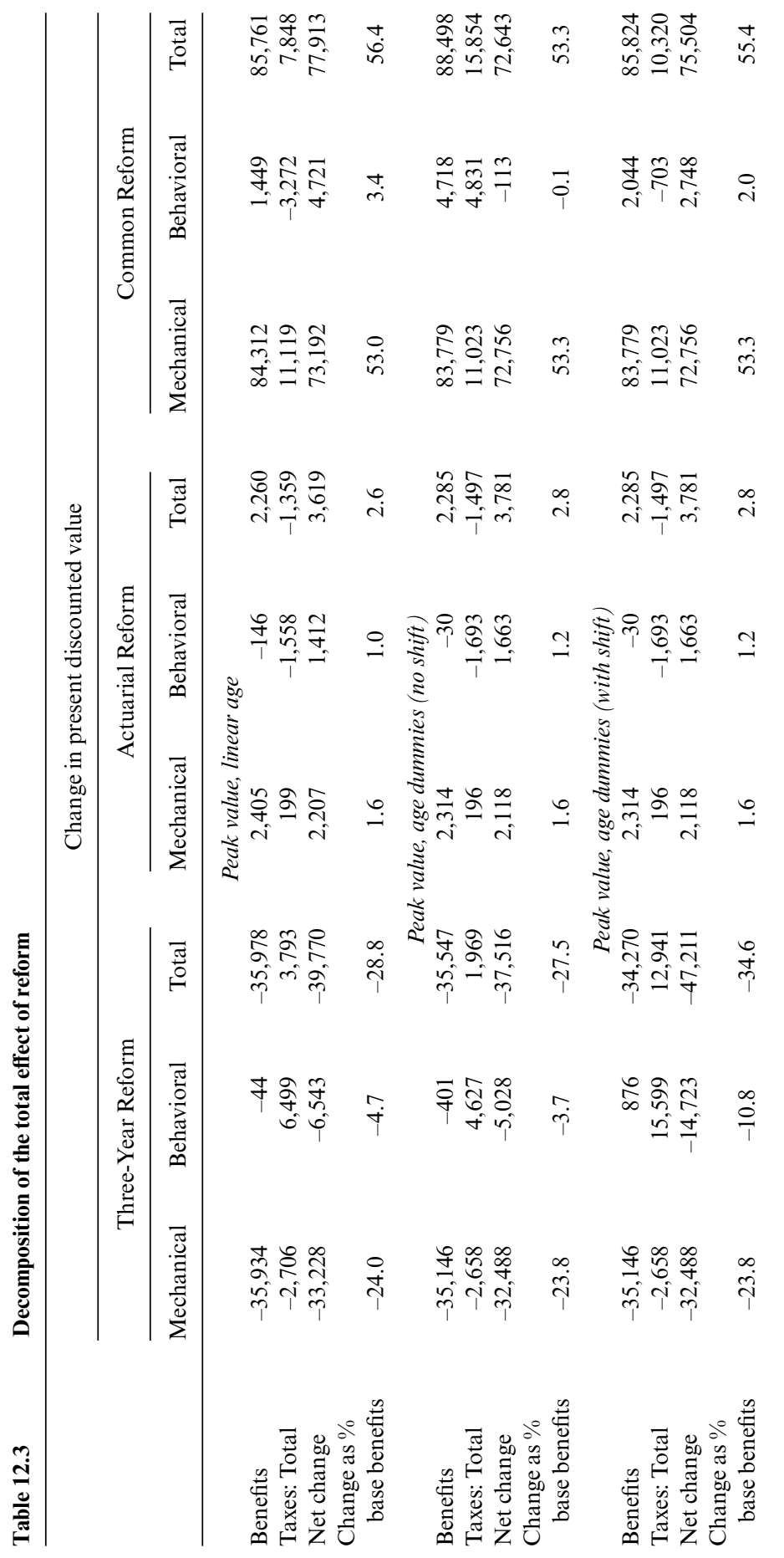




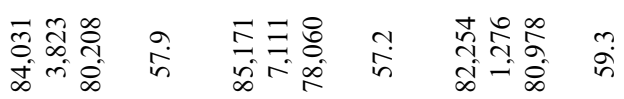

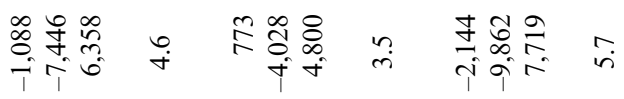

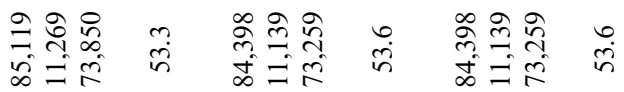

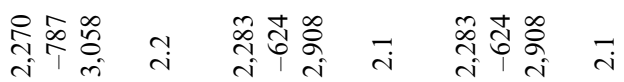

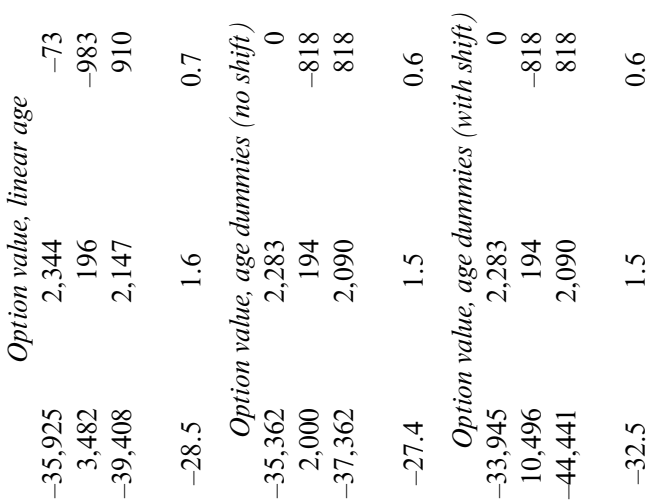

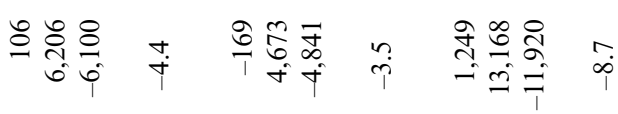

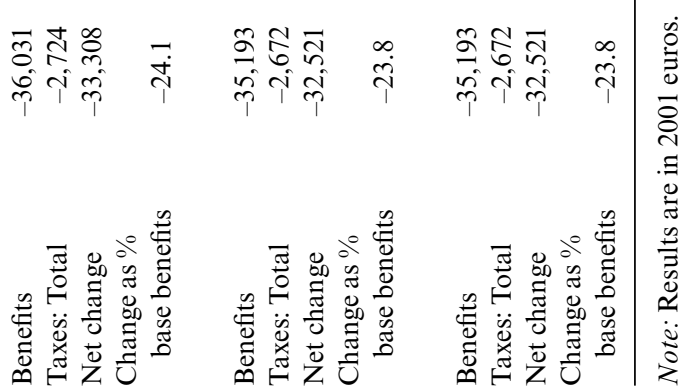


This is the case for the other two reforms as well. For both the Actuarial Reform and the Common Reform, the vast majority of the effect on Social Security payments is through the mechanical effect.

In the case of taxes, the behavioral effect is often larger than the mechanical effect and can vary significantly across models. For example, in the first panel of table 12.3, the mechanical effect of the Three-Year Reform is to reduce taxes by $€ 2,706$, while the behavioral effect is to raise taxes by $€ 6,499$, so that taxes increase on net. For this reform, the behavioral effect on taxes is particularly pronounced in the models with age dummy shifts in the third and sixth panels. On the other hand, for the Common Reform, the mechanical effects of taxes are much larger in all cases, although the offsetting behavioral effects are of a similar order of magnitude in the option value model with shifting age dummies.

The final rows of each panel in table 12.3 show the net change in the government's fiscal position for this cohort as a result of reform, and that net change as a percentage of baseline benefits. For the Three-Year Reform, we find that there is a total reduction in net government outlays of roughly $€ 40,000$ to $€ 47,000$, depending on the model. This represents 28 to 35 percent of baseline benefits. The majority of this impact comes from mechanical effects. At most one third, and generally less than one fifth, comes from behavioral effects, and this is exclusively through the tax side.

As noted, the impacts of the Actuarial Reform are much more modest. There is an increase in government outlays of $€ 3,000-€ 3,800$, or $2-2.8$ percent of baseline benefit payments. In this case, behavioral effects play a larger role, explaining about one third of the total change in fiscal position.

The Common Reform has the most substantial impact on fiscal positions. Net payments rise by over 50 percent in all simulations. This case also features the smallest relative contribution from behavioral responses; only about 10 percent or less of the effect of reform comes through behavioral responses. This is because most of the fiscal impact of this reform is on the benefits side, not the tax side, so that the small behavioral effect on benefits implies a small behavioral effect overall.

To better understand why the fiscal implications of the behavioral effect on social security wealth are relatively small, it is useful to recall that this is the additional effect of labor supply responses on fiscal balances, holding social security wealth constant at the postreform level. In order for the labor supply responses to have an additional effect on Social Security finances, two conditions must be met: reforms must significantly impact retirement decisions, and the Social Security system (benefits net of payroll taxes) must be less or more than actuarially fair. Even if there is no additional beneficial effect on Social Security program finances, reforms may improve overall government finances if they encourage workers to retire later and this results in higher lifetime income and consumption taxes.

Figure 12.1 shows Social Security benefits by age of retirement in the 


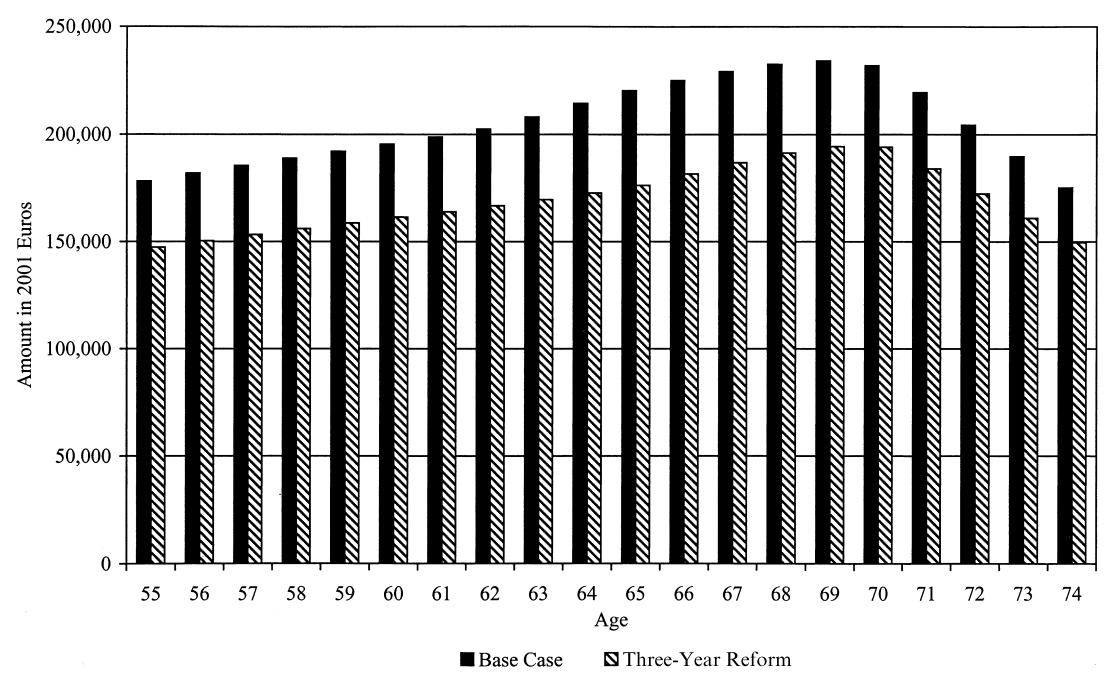

Fig. 12.1 Social Security benefits by age of labor force exit, Three-Year Reform

base case and in the Three-Year Reform case. In the base case, social security wealth rises with age of retirement until peaking at age 69 , making it appear that the system provides some return to additional work. However, when payroll taxes are included, the system is close to actuarially fair. For example, social security wealth in the base case rises from about $€ 195,000$ at age 60 to about $€ 234,000$ at age 69; however, the increase in payroll taxes over the same period (not shown on the graph) is about $€ 44,000$, making the net return to additional work a loss of approximately $€ 5,000$. Under the Three-Year Reform, benefits are lower but the system (including payroll taxes) remains roughly actuarially fair. Thus, even if this policy change induces people to change their retirement behavior, such changes will have little fiscal impact on the Social Security system, because it is close to actuarially fair.

Figure 12.2 illustrates how the sum of payroll, income, and consumption taxes varies with age of retirement. As discussed previously with respect to payroll taxes, the present discounted value of lifetime taxes rises with age, and this is true for other types of taxes as well. However, while the rise in payroll taxes roughly counteracts the rise in Social Security benefits with later labor force exit, the total rise in taxes greatly exceeds the rise in benefits. As a result, the net fiscal implications of longer work lives is positive: while Social Security is roughly actuarially fair, the increase in income and consumption taxes imply gains to the government from longer work lives.

Figure 12.3 shows the distribution of retirement ages pre- and postreform in the option value model with no shift of the age dummies. The reform is found to reduce the probability of retirement slightly at ages 55 to 


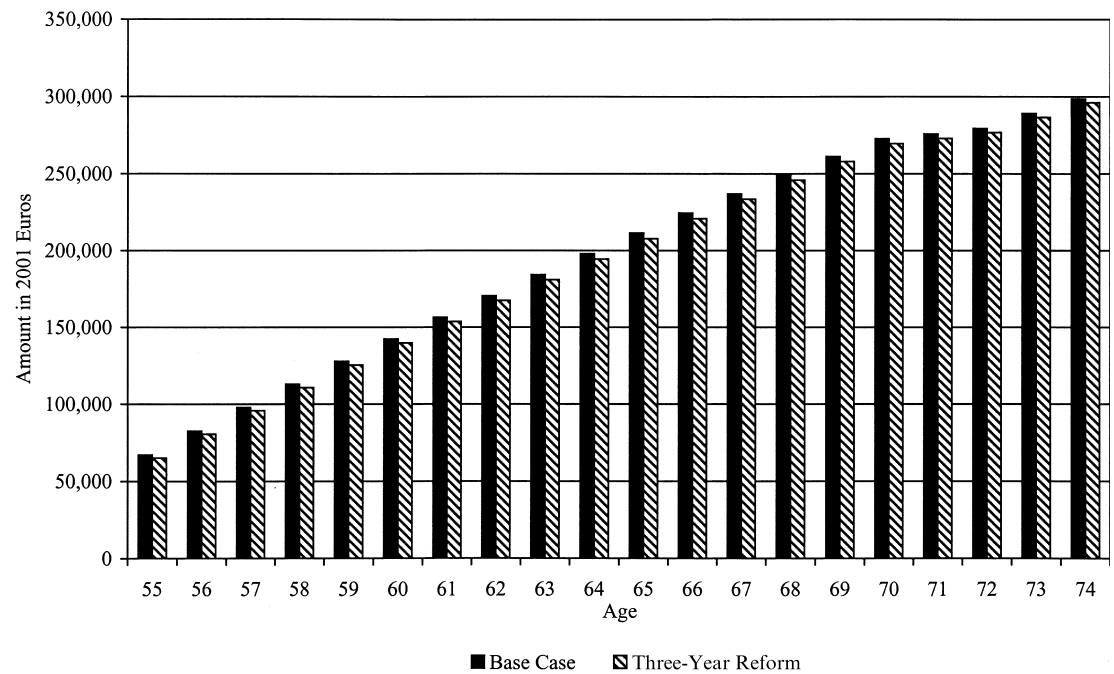

Fig. 12.2 Total taxes by age of labor force exit, Three-Year Reform

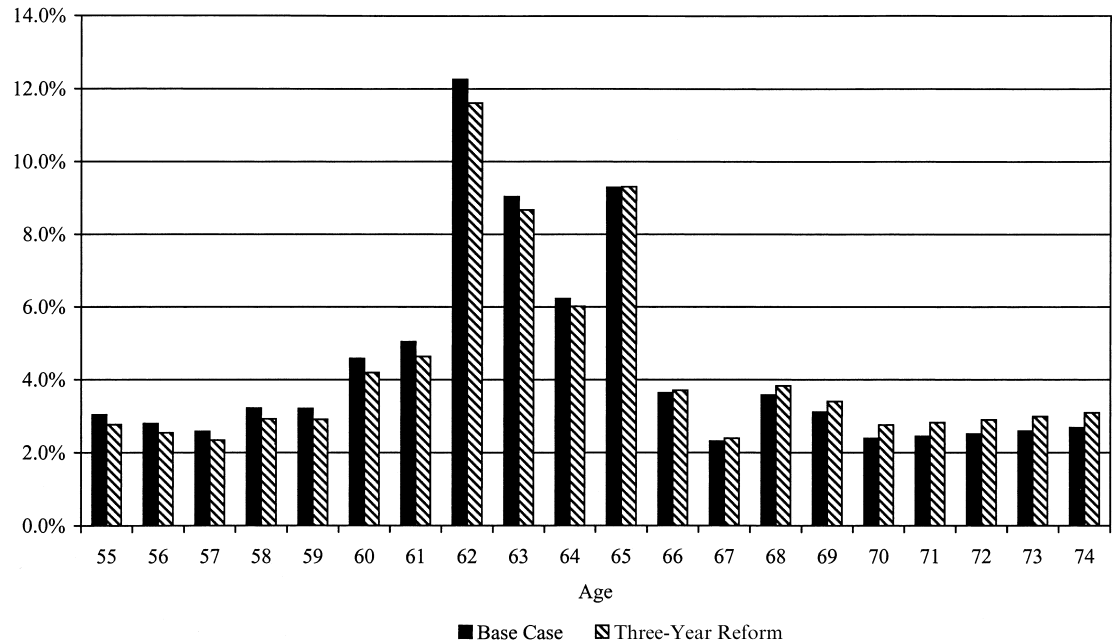

Fig. 12.3 Distribution of retirement ages, Three-Year Reform, option value-age dummies (no shift)

64 and to increase it slightly at ages 66 to 74 . But these effects are, in general, fairly small. Thus, it should not be surprising that there is relatively little behavioral effect on fiscal positions from this reform: there is relatively little impact on behavior, and any changes in behavior have modest impacts, because the system is roughly actuarially fair. 


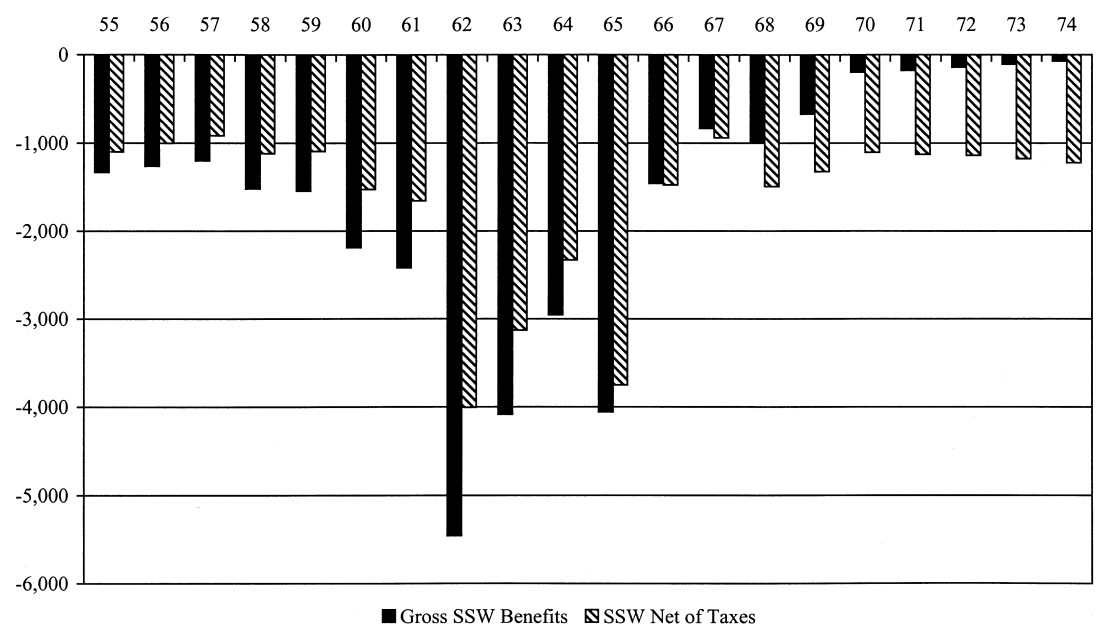

Fig. 12.4 Total effect by age of retirement, Three-Year Reform, option value-age dummies (no shift)

Figure 12.4 puts the information in figures 12.1 to 12.3 together to show the total effect of the reform on social security wealth, both gross and net of all taxes, by age of retirement. The gross and net effects by age are always negative, as this reform is a large benefit cut. The effects are largest at ages 62 to 65 , because the retirement probabilities are relatively high at these ages; put simply, most of the fiscal savings from this reform come from people who retire at ages 62 to 65 , because there are so many of them.

Figures 12.5 and 12.6 repeat figures 12.3 and 12.4, under the assumption that the age dummies shift by three years as a result of the reform. Here, there are much larger behavioral responses to reform, since we are by construction assuming that there is an enormous change in retirement behavior (by shifting the age dummy coefficients). As one would expect, the retirement probabilities now decline sharply at ages 62 to 64 and rise sharply at ages 65 to 68 . As a result, the reform now saves a larger amount of money at ages 62 to 64, since there are so many fewer people retiring then, but costs more money at ages 66 to 68 because of the increase in people retiring at those ages.

Finally, figure 12.7 compares the fiscal implications of reform for one birth cohort as a percentage of GDP for the six models used. In all cases, the mechanical effect leads to a savings of about 0.45 percent of GDP and the behavioral effect leads to an additional savings of about 0.10 percent of GDP, and slightly more in models with age dummy shifts. Thus we conclude that most of the effect of the policy reform on government finances results from the mechanical effect of the change. Labor supply responses to the policy have little additional effect on Social Security program sol- 


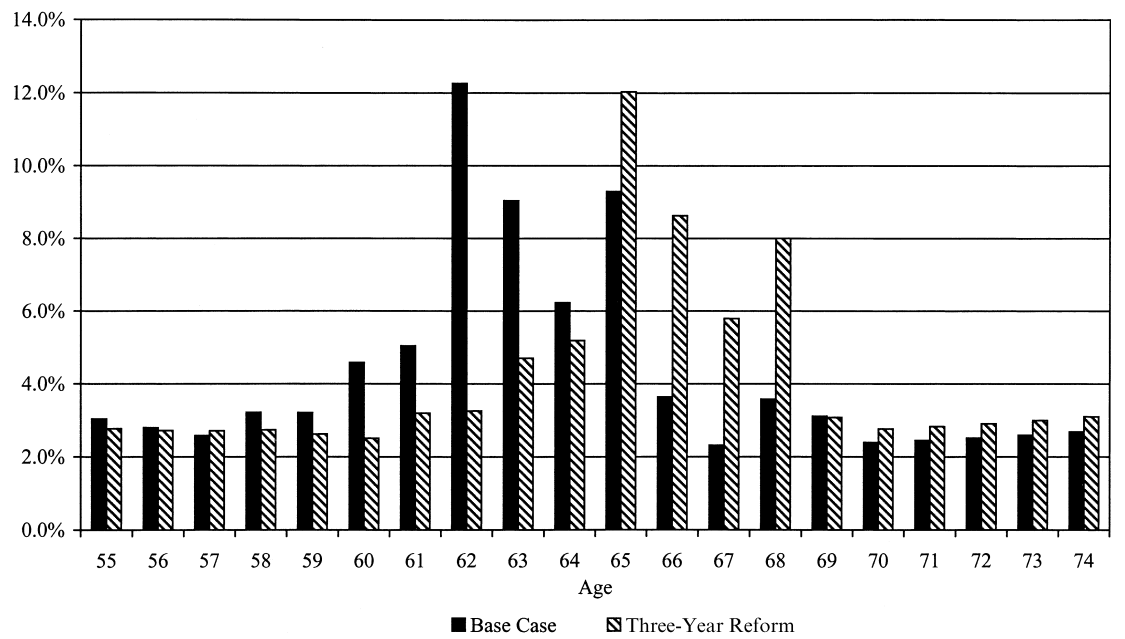

Fig. 12.5 Distribution of retirement ages, Three-Year Reform, option value-age dummies (with shift)

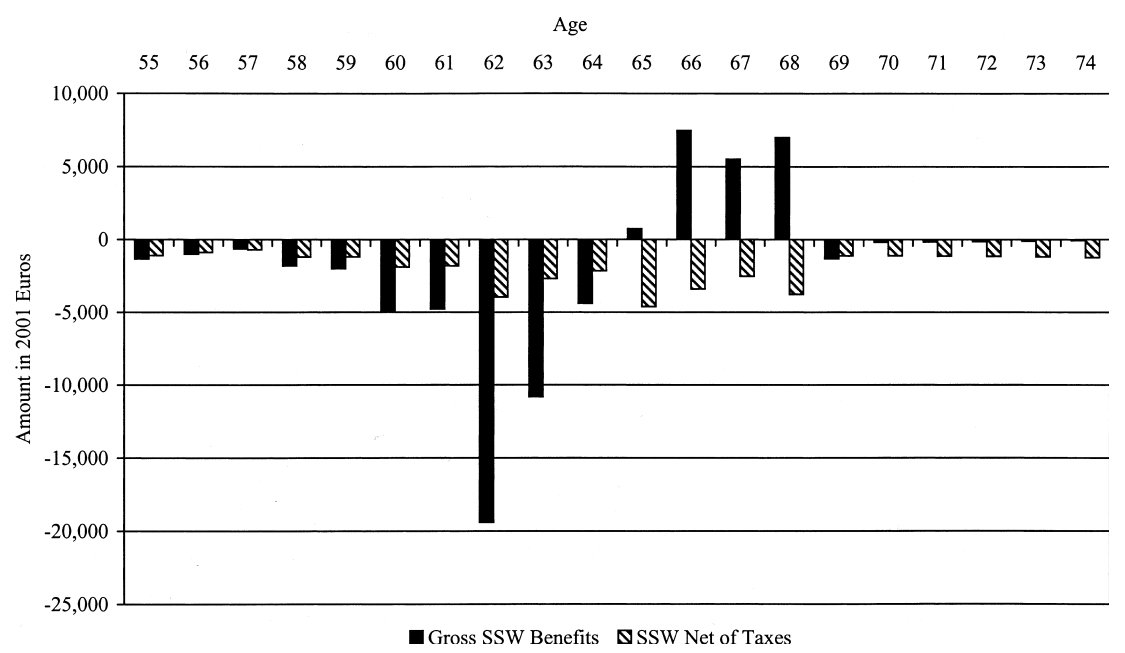

Fig. 12.6 Total effect by age of retirement, Three-Year Reform, option value-age dummies (with shift)

vency because the system is close to actually fair, though they do have a small beneficial effect on total government finances as a result of higher lifetime income and consumption taxes paid.

Next, we examine whether this finding will also apply to the two other reforms, the Actuarial Reform and the Common Reform. Figure 12.8 shows that the system is roughly actuarially fair (once payroll taxes are included) 


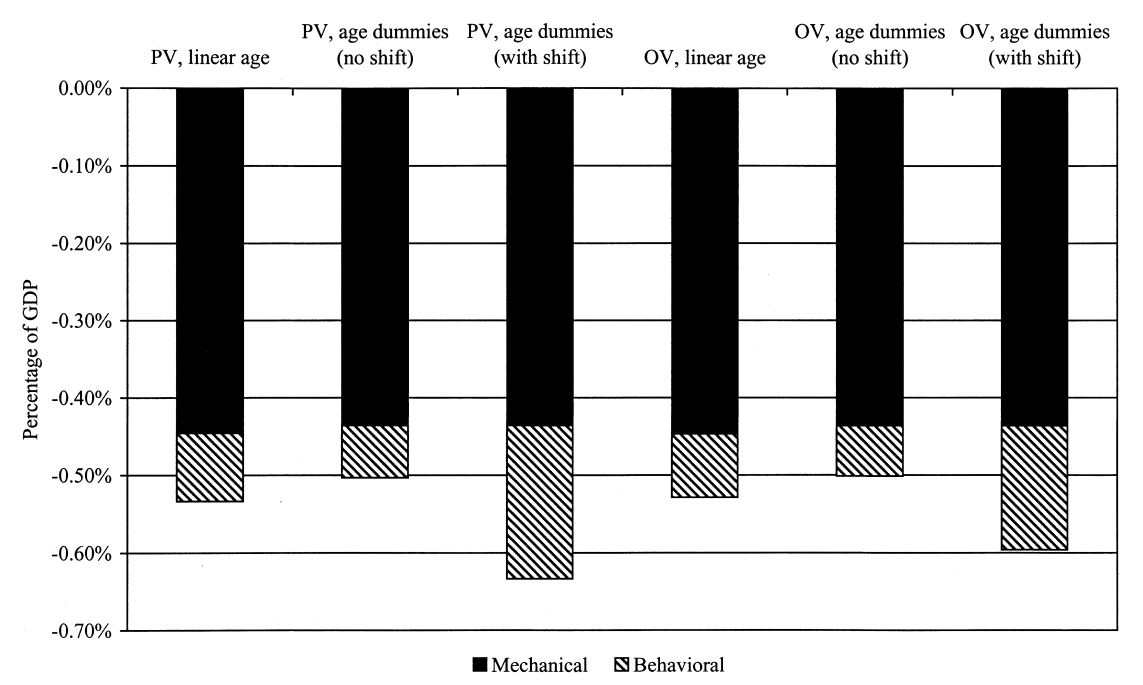

Fig. 12.7 Fiscal implications of reform as a percent of GDP: Three-Year Reform

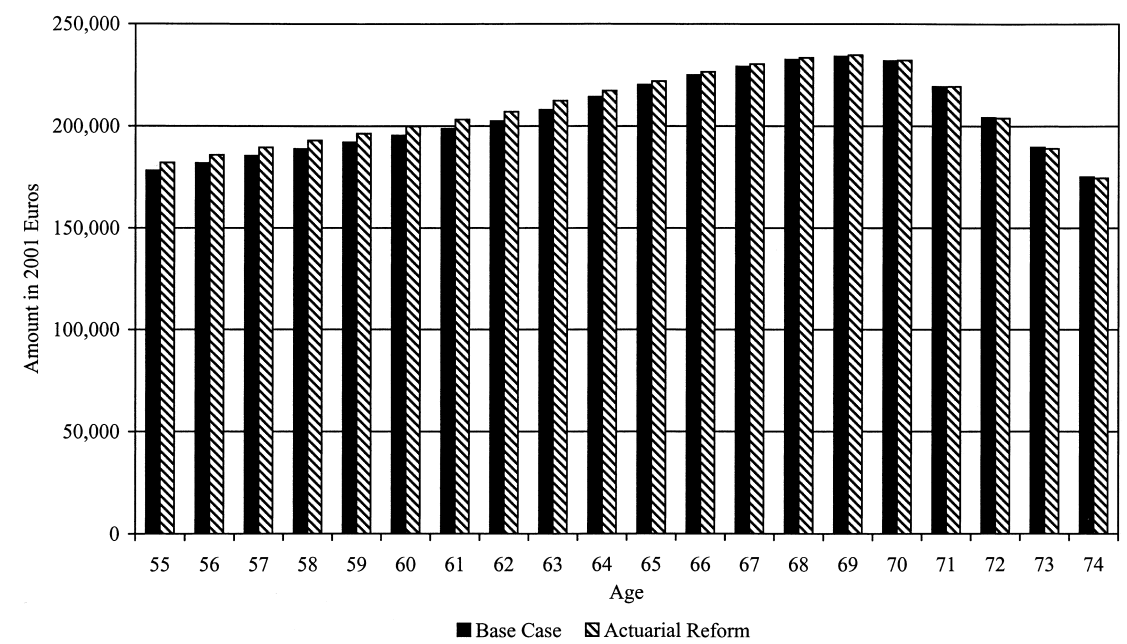

Fig. 12.8 Social Security benefits by age of labor force exit, Actuarial Reform

in both the base case and Actuarial Reform. Figure 12.9 shows that there are only small changes in retirement probabilities resulting from this reform in the option value model with no age dummy shift. Figure 12.10, like figure 12.7, compares the fiscal implications of this reform using all six models. As the reform represents only a small change from the current U.S. system, it is found to cause a mechanical increase in the cost of the program 


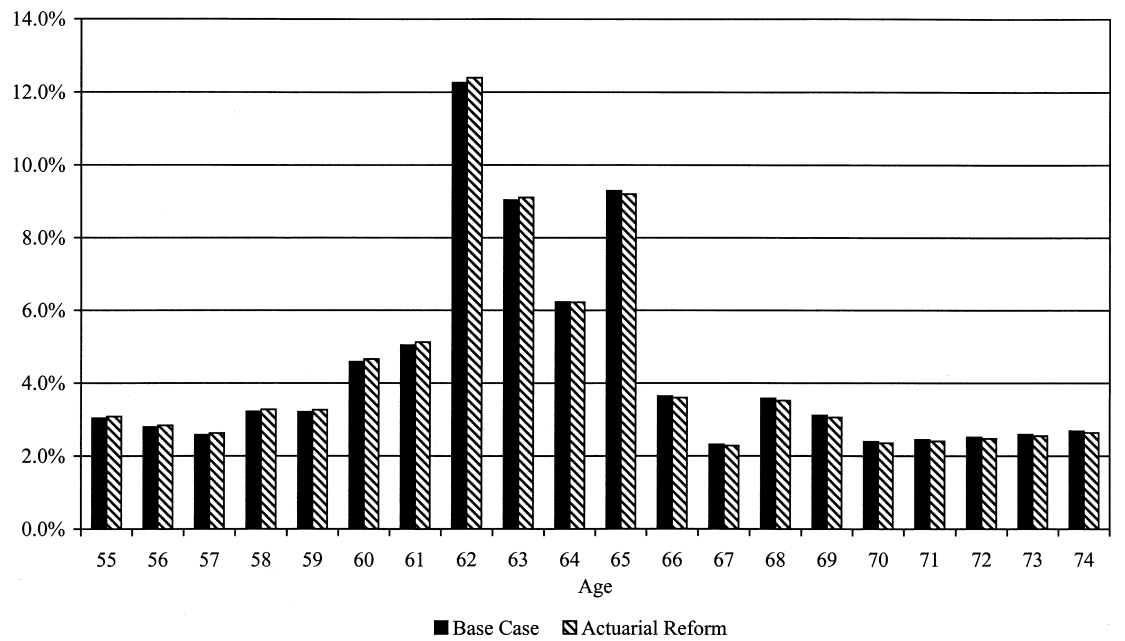

Fig. 12.9 Distribution of retirement ages, Actuarial Reform, option value-age dummies (no shift)

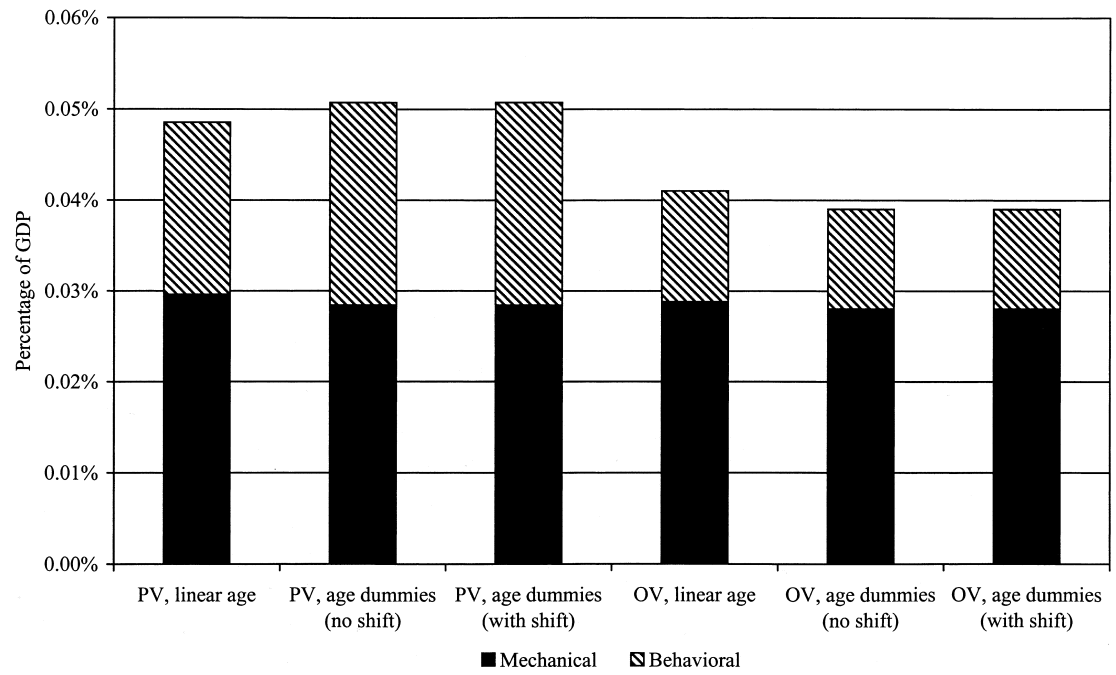

Fig. 12.10 Fiscal implications of reform as a percentage of GDP: Actuarial Reform

of only 0.03 percent of GDP; the behavioral effect raises the cost by an additional 0.01 percent -0.02 percent of GDP.

Figures 12.11 to 12.13 explore the effects of the Common Reform. Under this reform, the system is now more than actuarially fair, as the generous 60 percent replacement rate rewards additional work by more than enough to offset the additional payroll taxes. For example, working from 


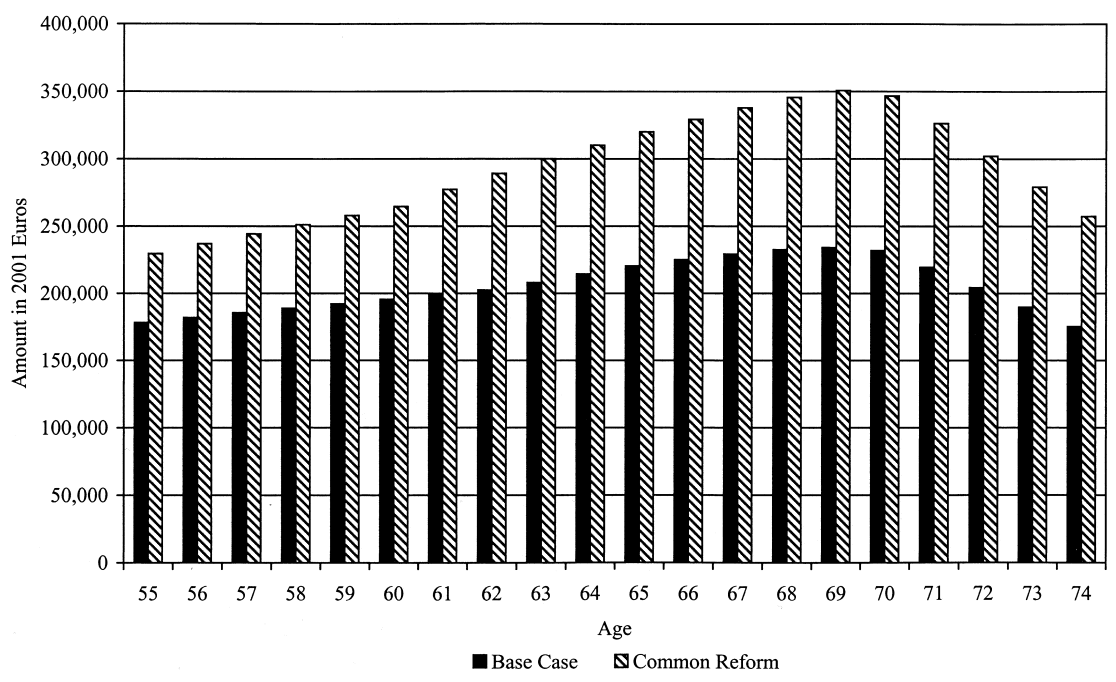

Fig. 12.11 Social Security benefits by age of labor force exit, Common Reform

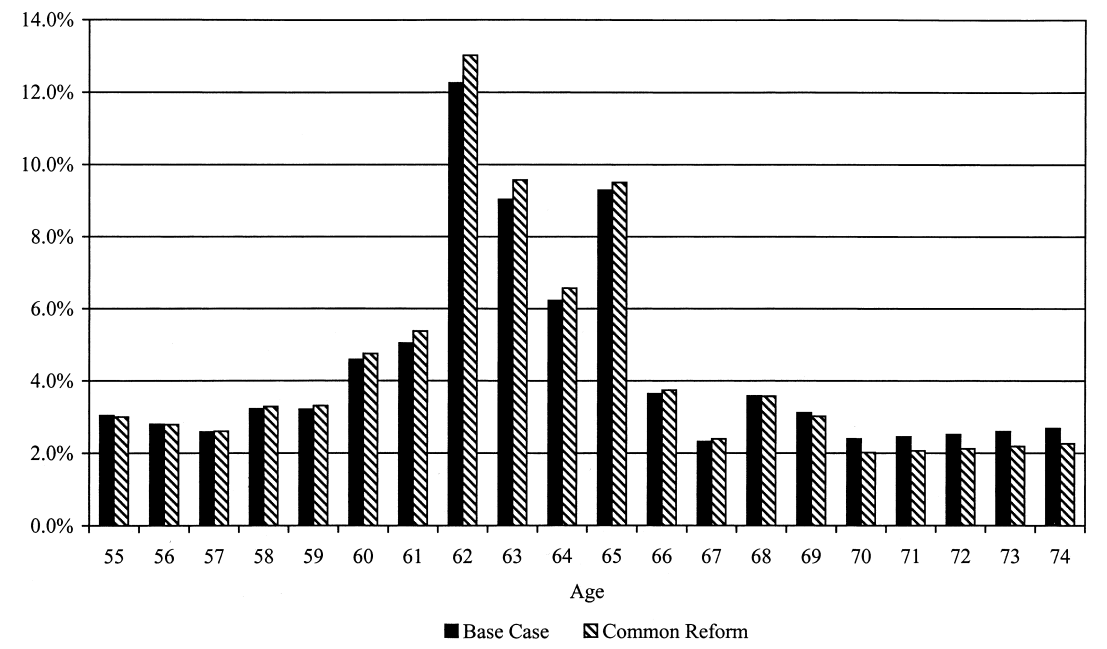

Fig. 12.12 Distribution of retirement ages, Common Reform, option value-age dummies (no shift)

age 60 to age 69 raises social security wealth net of payroll taxes by over $€ 41,000$. Due to the wealth effect, this reform induces people to retire earlier, as shown in figure 12.12; as the system is more than fair, earlier retirement will benefit Social Security program finances, though it will hurt overall government finances by lowering lifetime income and consumption taxes. As shown in figure 12.13, the fiscal implications of this reform are a 


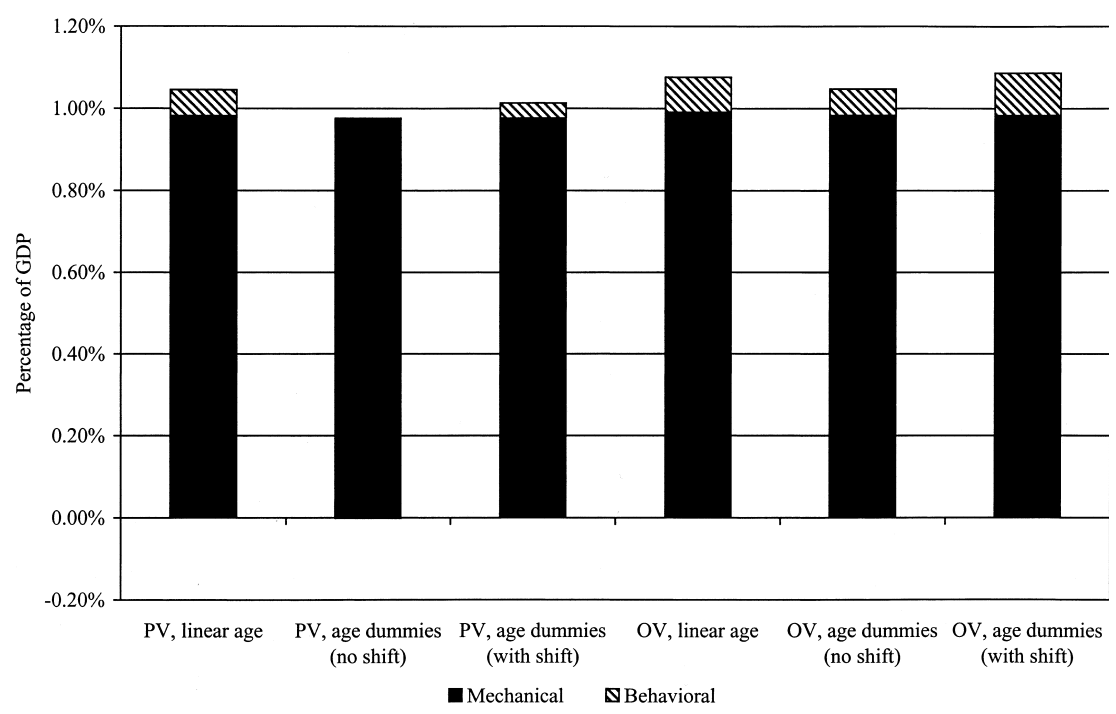

Fig. 12.13 Fiscal implications of reform as a percent of GDP

mechanical increase in program costs of almost 1 percent of GDP and an additional increase in costs of 0.1 percent- 0.2 percent of GDP as a result of the behavioral response, as workers retire earlier and pay fewer taxes.

To restate our central conclusion, the fiscal implication of the behavioral effect is quite small relative to the mechanical effect of the reforms, typically on the order of 10-20 percent of the total effect. Reforms may lead to significant changes in retirement behavior, particularly in models including shifts of the age dummies. However, as the Social Security system (including payroll taxes) is roughly actuarially fair, inducing earlier or later retirement has only a second-order effect on program solvency, though it may affect overall government finances by changing the amount of lifetime income and consumption taxes paid.

\subsection{Distributional Analysis}

Finally, we examine the effect of these reforms on people in different parts of the income distribution. Tables 12.4 and 12.5 show the effect of the three reforms by family AIME quintile using the option value models, first without (table 12.4) and then with (table 12.5) shifts of the age dummies. This comparison implicitly highlights the importance of behavioral effects, since these effects are much larger in the model with age dummy shifts.

In the model without an age dummy shift, the Three-Year Reform is found to affect all quintiles similarly: the change in Social Security benefits net of all taxes is equal to a loss of 19.8 percent of base benefits for the top 


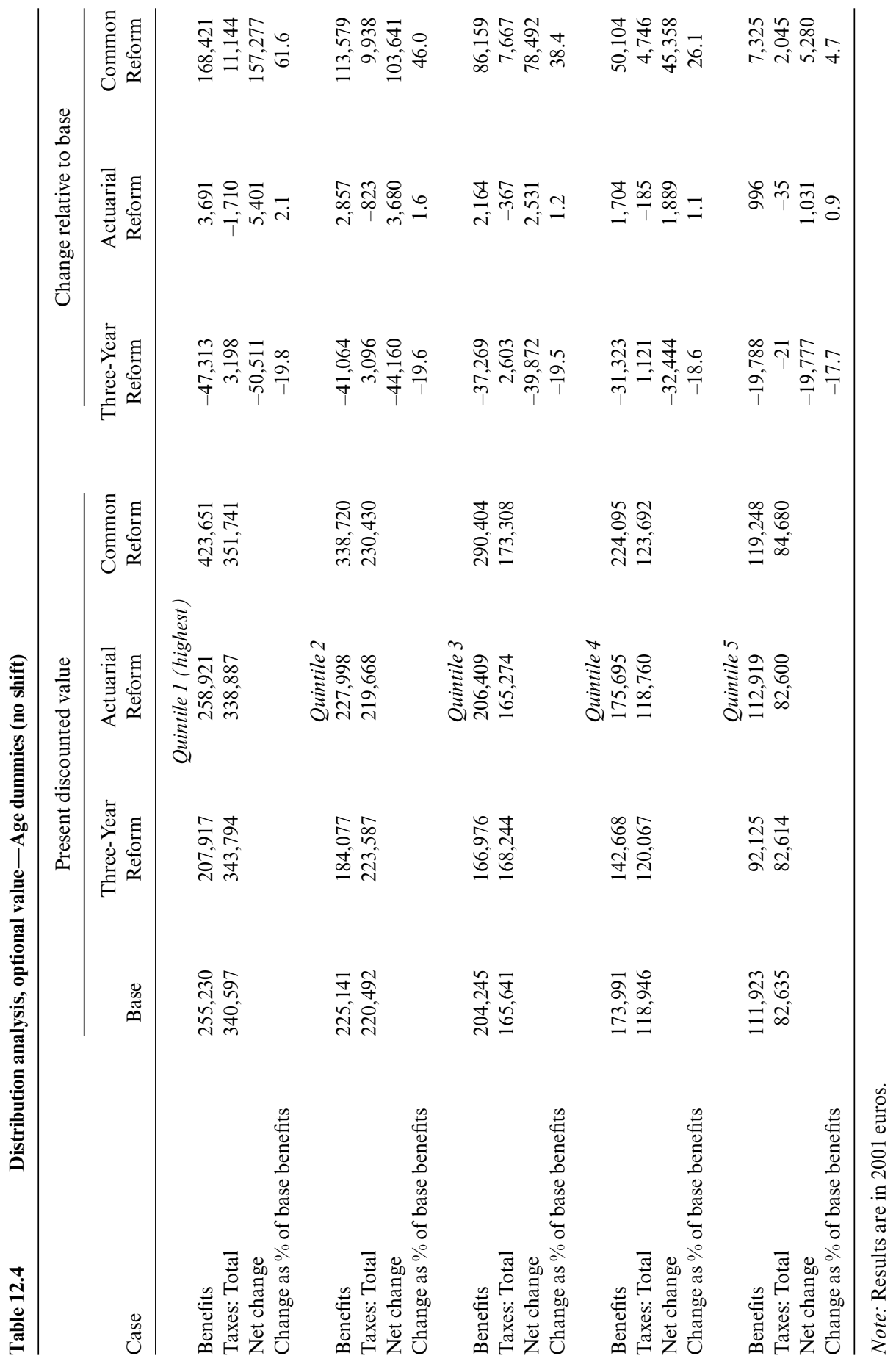




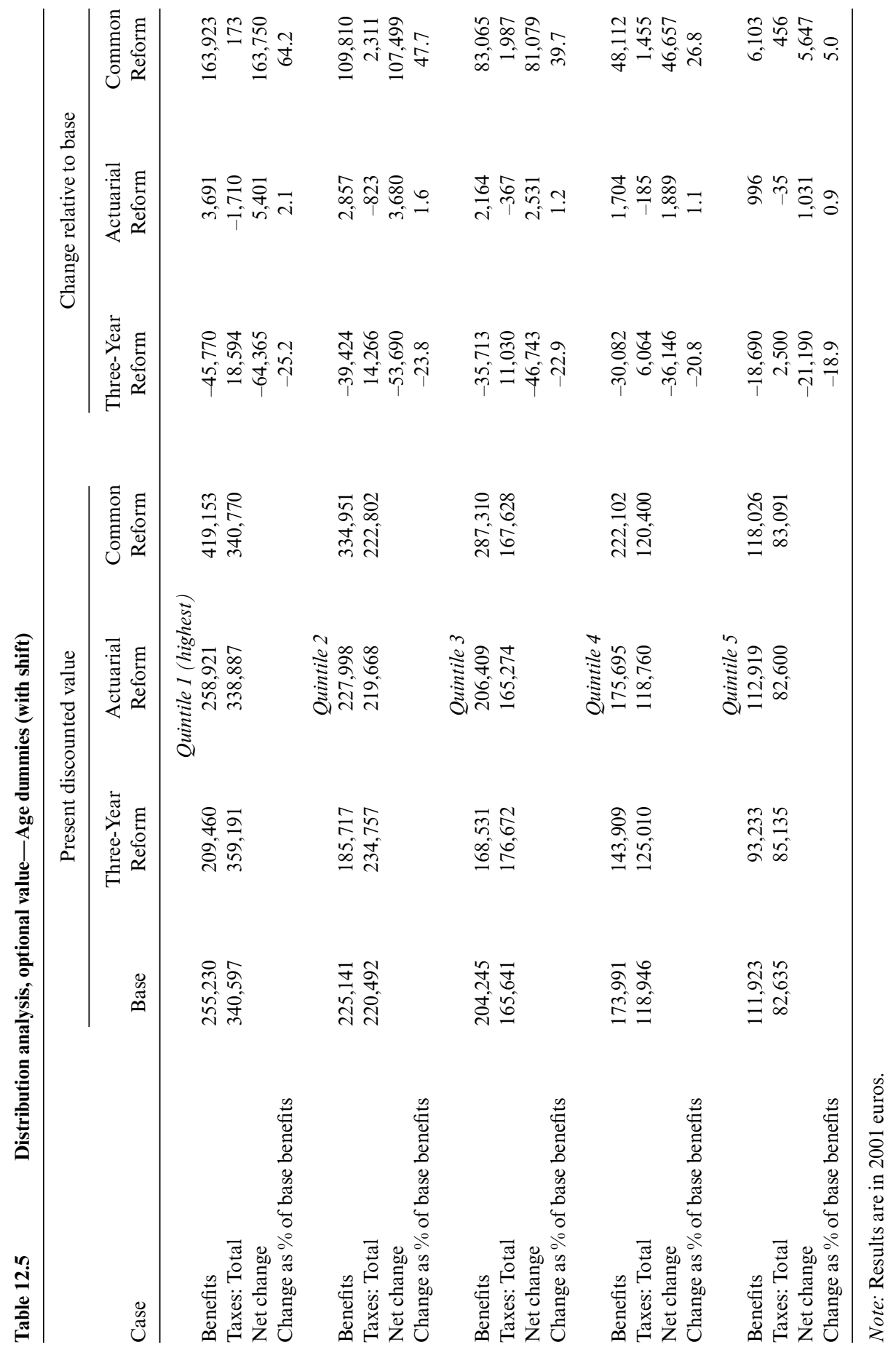


quintile versus a loss of 17.7 percent of base benefits for the lowest quintile; naturally, the absolute dollar losses are much larger for the top quintile. In the model with an age dummy shift, however, the top quintile experiences a relatively larger loss, 25.2 percent versus 18.9 percent for the lowest quintile. This suggests, therefore, that the behavioral response to the reform is either reducing benefits or increasing tax payments by a larger amount for the highest income quintiles. This effect appears to operate mostly through taxes: given that income taxes are progressive, longer work lives lead to a larger increase in tax payments over the work life for higherincome groups. That is, the longer work life in table 12.5 relative to table 12.4 leads to about $€ 18,000$ more in tax payments for the highest income quintile, but only $€ 2,500$ more for the lowest income group.

In the Actuarial Reform, gains are small for all quintiles, though they are twice as large as a percent of base benefits ( 2.1 percent versus 0.9 percent) for the highest quintile relative to the lowest.

In the Common Reform, by contrast, benefits are highly skewed toward the upper quintiles, even in percentage terms. This is because the Common Reform replaces the progressive benefit formula in the current system with a flat 60 percent replacement rate. The top quintile receives an increase in social security wealth net of all taxes equal to 61.6 percent of base benefits, while the bottom quintile receives an increase equal to just 4.7 percent of base benefits; results are similar in the model with shifts of the age dummy.

\subsection{Conclusions}

Any Social Security reform designed to improve the solvency of the OASDI trust funds will automatically have a beneficial effect on Social Security program finances by cutting benefits or raising taxes (the mechanical effect). But the reform may have an additional beneficial effect on program finances (the behavioral effect) if it encourages workers to retire later and if the Social Security system is less than actuarially fair. Even if there is no effect on program finances, the reform may have a beneficial effect on government finances if it leads workers to retire later and raises the lifetime income and consumption taxes they pay.

We have developed here a microsimulation model to estimate the impact of several reforms to the Social Security system. This model incorporates the behavioral responses of retirement to Social Security entitlements estimated in our earlier work. We have two key findings from this exercise. First, major reforms to the system can have substantial impacts on fiscal balances. Raising the early and normal retirement age by three years improves net fiscal balances by roughly one third of baseline benefits. On the other hand, reducing the early retirement age to 60 and raising the replacement rate to 60 percent would lead to a deterioration of fiscal balances by over one half of baseline benefits. 
Second, behavioral responses to system reforms only contribute modestly to fiscal balance effects. This is because the Social Security system as a whole is roughly actuarially neutral. As a result, delaying retirement has little net impact on system finances. However, when other taxes are factored in, delaying retirement does increase net government revenue. Thus, behavioral effects on the system as a whole are not zero, but are dominated by the mechanical effects of reform.

\section{References}

Blau, David M. 1994. Labor force dynamics of older men. Econometrica 62 (1): 117-56.

Burtless, Gary. 1986. Social Security, unanticipated benefit increases, and the timing of retirement. Review of Economic Statistics 53:781-805.

Coile, Courtney, and Jonathan Gruber. 2004. The effect of Social Security on retirement in the United States. In Social security and retirement around the world: Micro-estimation, ed. Jonathan Gruber and David A. Wise, 691-729. Chicago: University of Chicago Press.

Coile, Courtney, and Jonathan Gruber. 2000. Social security and retirement. National Bureau of Economic Research Working Paper no. 7830. Cambridge, MA: National Bureau of Economic Research.

- 2001. Social Security incentives for retirement. In Themes in the economics of aging, ed. David Wise, 311-41. Chicago: University of Chicago Press.

Diamond, Peter, and Jonathan Gruber. 1998. Social security and retirement in the United States. In Social security and retirement around the world, ed. Jonathan Gruber and David A. Wise, 437-73. Chicago: University of Chicago Press.

Diamond, Peter, and Jerry Hausman. 1984. Retirement and unemployment behavior of older men. In Retirement and economic behavior, ed. H. Aaron and G. Burtless, 97-134. Washington, DC: Brookings Institution.

Fields, Gary S., and Olivia S. Mitchell. 1984. Economic determinants of the optimal retirement age: An empirical investigation. Journal of Human Resources 19 (2): 245-62.

Gustman, Alan L., and Thomas L. Steinmeier. 1985. The 1983 Social Security reforms and labor supply adjustments of older individuals in the long run. Journal of Labor Economics 3 (2): 237-53.

-1986. A structural retirement model. Econometrica 54 (3): 555-84.

Hausman, Jerry A., and David A. Wise. 1985. Social Security, health status, and retirement. In Pensions, labor, and individual choice, ed. David A. Wise, 159-92. Chicago: University of Chicago Press.

Hurd, Michael D. 1990. Research on the elderly: Economic status, retirement, and consumption and saving. Journal of Economic Literature 28 (2): 565-637.

Ruhm, Christopher. 1995. Secular changes in the work and retirement patterns of older men. Journal of Human Resources 30:362-85.

Rust, John, and Christopher Phelan. 1997. How Social Security and Medicare affect retirement behavior in a world of incomplete markets. Econometrica 65 (4): 781-831.

Samwick, Andrew A. 1998. New evidence on pensions, Social Security, and the timing of retirement. Journal of Public Economics 70 (2): 207-36. 
Stock, James H., and David A. Wise. 1990a. Pensions, the option value of work, and retirement. Econometrica 58 (5): 1151-80.

1990b. The pension inducement to retire: An option value analysis. In The economics of aging, ed. David Wise, 205-29. Chicago: University of Chicago Press. 
